\title{
Perspectives on Utilization of Edible Coatings and Nano-laminate Coatings for Extension of Postharvest Storage of Fruits and Vegetables
}

\author{
María L. Flores-López ${ }^{1} \cdot$ Miguel A. Cerqueira ${ }^{1}$. \\ Diana Jasso de Rodríguez ${ }^{2}$ António A. Vicente ${ }^{1}$
}

Received: 22 April 2015/ Accepted: 22 September 2015/Published online: 6 October 2015

(c) Springer Science+Business Media New York 2015

\begin{abstract}
It is known that in developing countries, a large quantity of fruit and vegetable losses results at postharvest and processing stages due to poor or scarce storage technology and mishandling during harvest. The use of new and innovative technologies for reducing postharvest losses is a requirement that has not been fully covered. The use of edible coatings (mainly based on biopolymers) as a postharvest technique for agricultural commodities has offered biodegradable alternatives in order to solve problems (e.g., microbiological growth) during produce storage. However, biopolymer-based coatings can present some disadvantages such as: poor mechanical properties (e.g., lipids) or poor water vapor barrier properties (e.g., polysaccharides), thus requiring the development of new alternatives to solve these drawbacks. Recently, nanotechnology has emerged as a promising tool in the food processing industry, providing new insights about postharvest technologies on produce storage. Nanotechnological approaches can contribute through the design of functional packing materials with lower amounts of bioactive ingredients, better gas and mechanical properties and with reduced impact on the sensorial qualities of the fruits and vegetables. This work reviews some of the main factors involved in postharvest losses and new technologies for extension of postharvest storage of fruits and
\end{abstract}

Miguel A. Cerqueira

miguelcerqueira@deb.uminho.pt

1 Centre of Biological Engineering, Universidad do Minho, Campus de Gualtar, 4710-057 Braga, Portugal

2 Universidad Autonoma Agraria Antonio Narro, Calzada Antonio Narro No. 1923, Colonia Buenavista, 25315 Saltillo, Coahuila, Mexico vegetables, focused on perspective uses of edible coatings and nano-laminate coatings.

Keywords Shelf-life extension · Postharvest losses · Edible coatings $\cdot$ Nano-laminate coatings

\section{Introduction}

Around the world, agriculture and food industry suffer significant product losses from harvest to consumer, due to different factors involved. Such losses depend firstly on the management conditions existing in each region as well as on its economic resources. Thus in industrialized countries, more than $40 \%$ of the food losses (including cereals, roots and tubers, oilcrops and pulses, fruit and vegetables, meat, fish and dairy) occur at retail and consumer levels, while in developing countries, more than $40 \%$ of the food losses occur at postharvest and processing levels [52]. In the year 2011, Latin America presented the highest percentages of postharvest handling and storage losses (PHSL) in crops $(28 \%)$, while in industrialized countries (Europe and North America and Oceania), the percentages of PHSL were considerably minor (18 and $16 \%$, respectively; Table 1) [52].

Moreover, the largest postharvest losses in fruit and vegetable crops are due to deterioration caused by microorganisms after harvest and during cold storage. Fruits, due to their low $\mathrm{pH}$, higher moisture content and nutrient composition are very susceptible to the attack of fungi, while vegetables are generally less acidic, and their spoilage is usually by bacteria $[60,116]$. Although it is very difficult to determine the full extent of postharvest losses due to decay (i.e., attack by microorganisms and physical damages), it is wellknown that these losses are significant [78]. 
Table 1 Estimated/assumed postharvest handling and storage losses by region

\begin{tabular}{llll}
\hline Crop group $^{\mathrm{a}}$ & \multicolumn{3}{l}{$\begin{array}{l}\text { Postharvest handling and storage losses by } \\
\text { region }(\%)\end{array}$} \\
\cline { 2 - 4 } & $\begin{array}{l}\text { Europe } \\
\text { (incl. Russia) }\end{array}$ & $\begin{array}{l}\text { North America } \\
\text { and Oceania }\end{array}$ & $\begin{array}{l}\text { Latin } \\
\text { America }\end{array}$ \\
\hline Cereals & 4 & 2 & 4 \\
Fruits and vegetables & 5 & 4 & 10 \\
Roots and tubers & 9 & 10 & 14 \\
\hline
\end{tabular}

Adapted from Gustavsson et al. [52]

Fruits and vegetables: oranges and mandarins, lemons and limes, grapefruit, other citrus, bananas, plantains, apples, pineapples, dates, grapes, other fruit, tomatoes, onions, other vegetables

Roots and tubers: potatoes, sweet potatoes, cassava, yams, other roots

a Cereals (excluding beer): wheat, rice (milled), barley, maize, rye, oats, millet, sorghum, other cereals

The use of simple postharvest practices (e.g., selection of suitable harvest timing by maturity indices, cleaning of the product, sorting, packaging, quick cooling and good refrigerated storage and appropriate transportation and distribution) has been successful for small farmers when they are correctly applied. However, these practices do not always guarantee the produce integrity forcing producers to apply several treatments during postharvest preservation of food crops [126]. Chemical treatment is one of the postharvest techniques that are normally used before and after harvest to prolong shelf life and reduce food spoilage [36]. However, the lack of regulation in less developed countries has generated the indiscriminate use of pesticides in fruits and vegetables allowing the improvement of resistance of plagues to the most acceptable pesticides, while also affecting human health. Many of those pesticides have thus been removed from the market [17], consequently reducing the options for convenient and safe treatment of crops. Physical and quality losses are also due to deficient storage conditions, use of poor quality packages, rough handling, and a lack of suitable tools for postharvest management. These are the main reasons for losses of crops' market value and food safety, thus leading to low incomes for producers [66].

The increasing consumer demand for fresh fruits and vegetables of higher quality and more nutritious has encouraged the food industry to develop new and better methods for maintaining food quality and extending shelf life [9]. Recent studies of postharvest treatments, particularly the use of edible coatings and nano-laminate coatings, are receiving a growing interest by food industry. It is known that producers in developing countries are largely small farmers, rarely associated with formal organizations; therefore, the access to technical training, and in general, new postharvest technologies, is limited; also the scarcity of information about costs and financial benefits of using these new technologies is a problem. The implementation of a technology from the laboratory to the field represents an area of opportunity $[65,66]$.

This review presents a new insight about the application of edible coatings and nano-laminate coatings as potential postharvest technologies for fruits and vegetables storage.

\section{Parameters Involved in Fruit and Vegetables Postharvest Losses}

During harvesting, fruit and vegetables continue living despite being separated from their natural source of organic and mineral nutrients and water. The energy used to conduct these activities results from the respiration process; it involves the breakdown of carbohydrates to produce carbon dioxide, water and heat (Fig. 1). Also, the transpiration process takes place moving water vapor from the plant organs' surface to the surrounding air (Fig. 1) [26, 121]. These processes do not continue indefinitely, causing initial shrinkage and subsequent weight loss of the tissues (about $5-10 \%$ of their weight) [42]. Both respiration and transpiration processes are considered as the major causes of postharvest losses and poor quality in produce, and their control is important in order to extend produce shelf life [11].

The control of relative humidity $(\mathrm{RH})$ and temperature of storage is also important, since these are factors that play an important role in maintaining produce quality due to the direct influence they have on transpiration and respiration processes, as well as on the vapor gradient between the produce and the storage atmosphere. Then, when the produce is kept at a temperature similar to that of the storage environment, transpiration rate is highly correlated with the RH during storage [121]. It has been shown that high RH values during storage can reduce moisture losses and subsequently maintain fruit firmness by decreasing the transpiration rate of fruits or sub-cuticle evaporation, mainly under reduced air velocities and low temperature [56]. In addition, low temperature $\left(4-8{ }^{\circ} \mathrm{C}\right)$ can reduce respiration rate, increase tissue resistance to ethylene action, delay compositional breakdown of macromolecules, retard senescence, and control the development of rot microorganisms [126]. However, at such temperatures, some tropical native fruits and vegetables can present chilling injuries. Due to the influence of these factors (i.e., $\mathrm{RH}$, temperature), each produce has its own ideal set of conditions that allow a successful storing for the maximum length of time, although RH levels around of 85-95\% are commonly recommended for the storage of fresh fruits and vegetables [121]. 
Fig. 1 Processes involved in the respiration of harvested produce

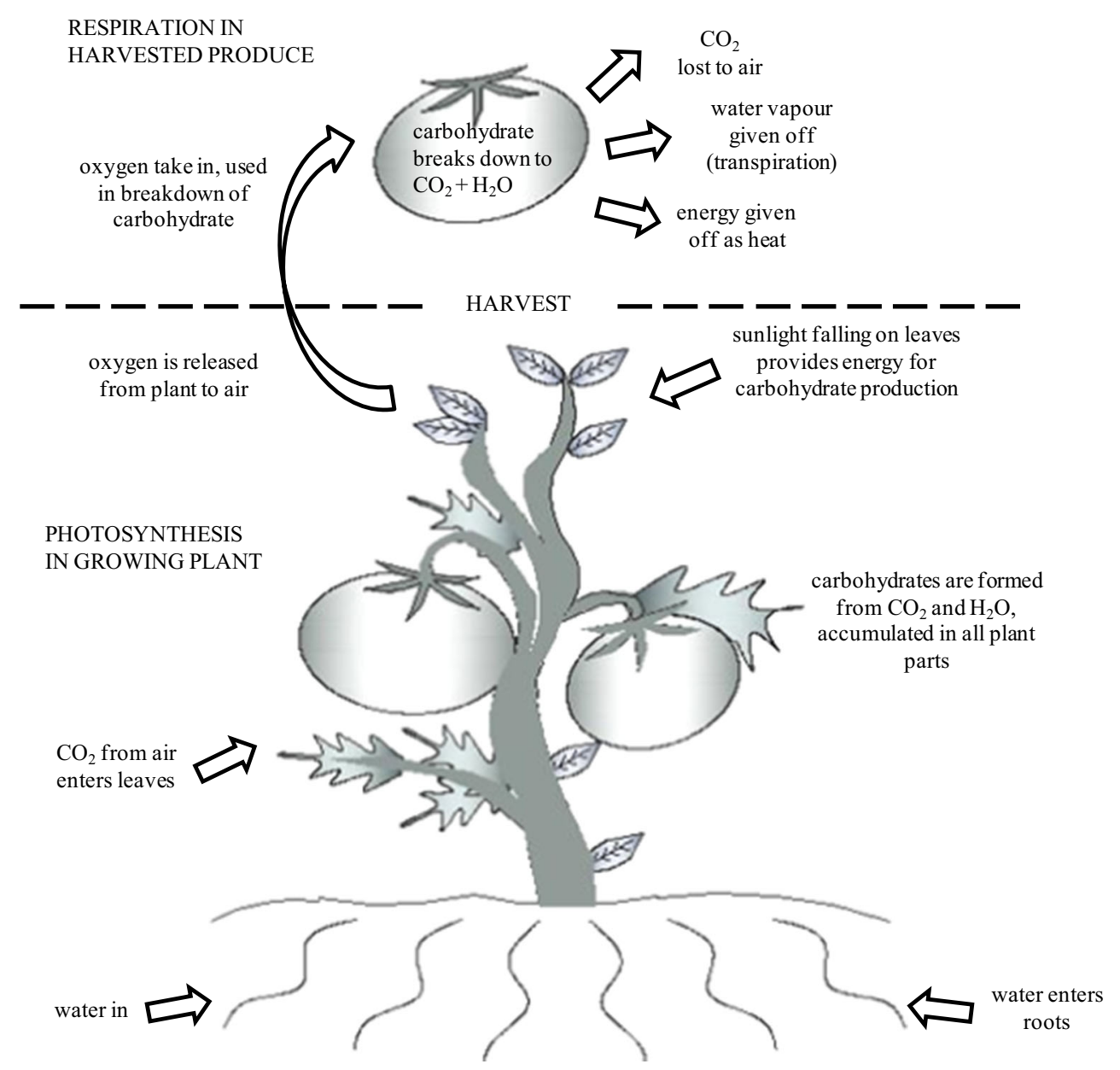

On the other hand, decreases in yield and quality of fruits and vegetables caused by pest damages (especially by fungi) during storage can be even higher than losses occurring in the field, and these are favored when the produce is not rapidly cooled or is not transported and stored in appropriate conditions [10]. Commonly, chemical treatment is a postharvest technique used before and after harvest to prolong shelf life and reduce food spoilage [36].

The use of biopesticides has emerged as one alternative substitute for chemical pesticides. Biopesticides are certain types of pesticides manufactured from living microorganisms (e.g., bacteria, fungi or viruses) or plant extracts (including secondary metabolites and essential oils) and other biochemicals (e.g., insect sex pheromones) [6, 24]. The increasing use of this kind of biocontrol is demonstrated with the recent approval of more than 430 biopesticides active ingredients and 1320 active products on the list of Environmental Protection Agency (EPA) [35].

Within microbial-based biopesticides, the use of antagonistic microorganisms, mostly bacteria and fungi, has shown their efficiency to control different postharvest rot pathogens of sweet cherries and table grapes [105], banana [27], citrus [18], pineapple [124], apple [76, 110], peach [95], potato
[99], tomato [70], and mandarin [59], among others. However, this type of biopesticides presents some disadvantages according to tests conducted under commercial or semicommercial conditions. More in detail, the use of formulated biopesticide preparations leads to inconsistency and variability in disease control level, being this one of the most significant barriers preventing widespread implementation of biocontrol technology $[33,36]$. Indeed, simple application of antagonistic microorganisms does not provide comparable control results to chemical pesticides [34], although it has been proven that the combination of antagonistic agents with innocuous exogenous substances, such as chitosan, amino acids, antibiotics, calcium or bicarbonate salts, has increased the level of protection against Penicillium digitatum and $P$. italicum on oranges [84].

Another promising alternative to chemical pesticides is the use of biopesticides based on plant extracts and essential oils (EOs) of aromatic plants [67]. These are denominated green pesticides since they are obtained manly employing organic solvents (e.g., water, ethanol, methanol and hexane). It is known that the antimicrobial activity depends on plant species as well as on the nature of solvent extract used; in this order, several works have been focused in obtaining new 
plant extracts and essential oils with acceptable antimicrobial activity [20]. Recently, methanolic extracts from nine wild edible herbaceous species showed the highest efficacy (in vitro and in vivo) against some important postharvest pathogens, i.e., Botrytis cinerea, Monilinia laxa, $P$. digitatum, P. expansum, P. italicum, Aspergillus carbonarius, and A. niger; the inhibition efficacy of these extracts was associated with the presence of some caffeic acid derivatives and/ or flavonoids [49]. Moreover, Jasso de Rodríguez et al. [62] reported effective antifungal activity (in vitro) of hexanic and ethanolic extracts of Mexican semi-desert plants against Rhizopus stolonifer, Colletotricum gloesporoides and $P$. digitatum; the authors reported that the effectiveness depends on the nature of extracting solvent used.

Biopesticides are accepted worldwide; however, their utilization still faces some important challenges such as: (1) poor stability - this is the major drawback of these products, which need improvement of their formulations for a better market acceptance; (2) packaging - it should be designed in such a way that the stability of the packaged products can be maintained during storage (e.g., no container swelling due to the growth of spoilage microorganisms); (3) shelf life-biopesticides shelf life is often low; (4) highly specific activity-causing that biopesticides will be niche products (thus with significantly lower sales) when compared with chemical products, with a broad spectrum of activity; and (5) distribution-being the major obstacle due to higher cost, leading to lower margins and limited training for sellers, distributors and farmers [122].

An attractive alternative to overcome these disadvantages and generate new postharvest technologies can be the incorporation of active agents used in formulation of biopesticides into edible coatings. The use of edible coatings can increase biopesticides' stability and shelf life and at the same time add new functionalities to the final product (e.g., decrease packaging gas transfer rates).

At this moment there are only a few biopesticide-based products applicable in the postharvest stage, since most of them are aimed at controlling preharvest pests. Also, it is known that most of the biopesticide producing companies are medium and small enterprises, therefore having limited resources for $\mathrm{R} \& \mathrm{D}$, product registration and promotion [24]; this highlights the importance of developing new and inexpensive technologies such as coating-based technologies.

\section{Edible Coatings to Increase Quality and Shelf Life of Fruit and Vegetables}

Currently, edible coatings have been successfully introduced in food processing due to the beneficial impact on the produce quality and environment, since they preserve the organoleptic properties of foods, retard moisture loss, create a barrier for gas exchange between the fresh fruit and the surrounding atmosphere, and reduce the use of disposable and non-degradable packaging materials, maintaining their organoleptic properties $[108,120]$. The major advantage of edible coatings is that they can be consumed with the packaged products [14]; therefore, all components used in their formulation should be classified and recognized GRAS (generally recognized as safe) and should have been approved to be consumed with the food products. Most edible coatings are based on polysaccharides, proteins and lipids, being used alone or in blends [72]; their mechanical and barrier properties depend strongly on the physical and chemical characteristics of their constituents [90].

\section{Lipids}

Lipid-based coatings are commonly made from waxes (e.g., carnauba wax, beeswax and paraffin wax), oils (e.g., mineral and vegetable oil) and resins (e.g., shellac wood rosin, coumarone-indene resin) [72]. These coatings have low polarity and because of that are effective for reducing water transmission [115]. Moreover, they provide protection on chilling injury and improve the appearance of the produce [32]. These coatings have been extensively used on whole fruit and vegetables; however, they show some disadvantages such as formation of cracks, lack of homogeneity, sensorial alterations, poor adhesion to the produce, and in some cases, the high gas barrier they establish leads to anaerobic conditions $[8,28]$. Their combination with polysaccharides or proteins may interact favorably, resulting in edible coatings with a good mechanical strength and controlled barrier characteristics [25, 119].

\section{Proteins}

A variety of proteins from natural sources have been used for edible coatings production, some examples are: casein, whey protein, collagen, gelatin, keratin, wheat gluten, soy protein, peanut protein, corn-zein and cotton seed protein [31]. These coatings usually exhibit good mechanical properties since they are structured by 20 different monomers (amino acids), allowing high potential for forming numerous linkages via disulfide (S-S) covalent bonding, electrostatic forces, hydrogen bonding and hydrophobic interactions. Protein-based coatings also present good oxygen barrier properties at low RH, although most of them are poor barriers against water vapor due to their hydrophilic nature [15]. Several procedures, including chemical and enzymatic modification of protein properties, combination with hydrophobic materials, and physical methods, have been performed in order to improve their barrier and mechanical properties [15]. 


\section{Polysaccharides}

Polysaccharide-based coatings have been the most commonly used to coat fruits and vegetables due to their appropriate adhesion and flexibility properties on the produce surface [97]. There is a great variety of polysaccharides from diverse sources used for elaboration of edible coatings; among the most common are: chitosan [77], galactomannans [21], pectin [129], alginate [45], carrageenan [55] and starch [104]. Depending on their chemical composition, they are able to: (1) regulate mass transfer processes involving oxygen [4, 81], carbon dioxide [44], water vapor [3], ethylene [44] and other volatile compounds [81]; and (2) have an effect on the mechanical properties of the food [43]. Polysaccharide-based coatings generally exhibit poor water vapor resistance due to their hydrophilic nature; despite of that characteristic some polysaccharides, applied in the form of high-moisture viscous coatings, are able to retard water loss from coated foods [63].

\section{Composites}

The blend of more than one material can lead to the development of composite edible coatings with interesting properties. The usual objective is to take advantage of the maximum possible performance of the blend without changing drastically the properties of their components. Mixtures between different polysaccharides, polysaccharides and proteins and polysaccharides and lipids and waxes are the most studied blends [23, 38, 46, 68, 71, 102].

\section{Plasticizers}

Within the study of coatings, improvement of mechanical and transport properties through the incorporation of other compounds (i.e., plasticizers and lipids) has been a constant subject of interest [12]. Plasticizers have been incorporated to enhance flexibility and resilience of coatings [107] and decrease the presence of cracks and pores [47]. A plasticizer acts by decreasing the intermolecular attraction between polymeric chains, allowing the penetration of polar water vapor molecules [63], highly influencing the final coating permeability. Water, oligosaccharides, polyols and lipids are different types of plasticizers used in hydrocolloid-based coatings [111]. Glycerol is one of the most used plasticizers; it is a hydrophilic molecule (polar) and increasing its concentration causes an increase in water vapor mass transfer. Cerqueira et al. [23] evaluated the influence of glycerol and corn oil on physicochemical properties of galactomannan from Gleditsia triacanthos and chitosan-based coatings, and confirmed that the presence of glycerol and corn oil originated a more hydrophilic structure and a decreased affinity of the coating matrix to water in both polysaccharides, respectively. Olivas and Barbosa-Cánovas [88] carried out a similar study, where the effect of four plasticizers (fructose, glycerol, sorbitol and polyethylene glycol) was evaluated on the mechanical properties and water vapor permeability (WVP) of alginate coatings. These authors reported that the use of plasticizers modified the mechanical properties of alginate coatings, decreasing tensile strength (TS), being this effect more pronounced when RH increases; also, results showed that water acts as a plasticizer in hydrophilic coatings.

\section{Edible Coatings as Carriers of Bioactive Molecules}

The favorable effects of edible coatings on fruits and vegetables (i.e., gas barrier and reduction in metabolic rate) have been extensively proven $[41,85,113]$. Edible coatings have the particularity to act as carriers for a wide range of food additives such as: antioxidants, nutraceuticals, flavoring agents and antimicrobials [93, 101]. Several antimicrobials can be incorporated into edible coatings, including organic acids (e.g., citric, lactic, acetic, benzoic, tartaric, propionic, and sorbic acid), polypeptides (e.g., lysozyme, lactoferrin, natamycin, nisin, and peroxidase), plant extracts and essential oils (e.g., cinnamon, capsicum, garlic, carvacrol, oregano, and lemongrass), mineral salts (e.g., sodium bicarbonate, ammonium bicarbonate, and sodium carbonate), parabenes, oligosaccharides (chitooligosaccharides), among others [89, 96, 98, 118]. These compounds must be considered as GRAS by the corresponding international regulatory agencies in order to be incorporated into edible coatings. Antimicrobials are regulated in the European Union (EU) by the European Commission Framework Directive 1130 [37], while in the USA by the part 21CFR172 [117].

Several authors observed through in vitro studies that the inclusion of antimicrobials into edible coatings enhances the control of rots that cause spoilage in fruits and vegetables. However, more studies of incorporation are necessary to understand how to maintain stable coating properties after bioactive incorporation (e.g., gases barrier, mechanical properties and appearance) [104]. For example, Mohamed et al. [83] evaluated the incorporation of lactoperoxidase system (LPOS), an antimicrobial of broad spectrum, into chitosan coatings at different concentrations $(0.5,1$ and $1.5 \%$ ); the addition of LPOS showed no significant effect on mechanical properties of the coatings, but led to a bacterial and fungal inhibitory effect depending on chitosan concentration and the strain on Xanthomonas campestris pv. Mangifera indica, Colletotrichum gloeosporioides and Lasiodiplodia theobromae. Meanwhile, Ahmad et al. [2] reported that properties of gelatin films from skin of unicorn leatherjacket were affected by the incorporation of bergamot 
(BO) and lemongrass oil (LO), resulting in decreases in tensile performance (i.e., tensile strength and elongation-atbreak), film solubility and transparency, being WVP also decreased when LO was added. The authors reported higher antimicrobial activity in films incorporated with LO than those with BO, being more effective against Gram-positive bacteria (Staphylococcus aureus and Listeria monocytogenes) than Gram-negative bacteria (Escherichia coli and Salmonella typhimurium), but showing no inhibition toward Pseudomonas aeruginosa.

Recent works addressed the incorporation of nanoemulsions into edible coatings as a method to disperse lipophilic active ingredients in lower doses and with increased effectiveness. In this context, Acevedo-Fani et al. [1] reported the suitability of nano-emulsions loaded with of EOs (thyme, lemongrass and sage oil) for formation of edible films by microfluidization. The results indicated that physical properties (color, barrier and mechanical) of resulting edible films were influenced by the droplet size and $\zeta$-potential, and were improved for those films including EOs when compared with pure alginate films; furthermore, authors mentioned that antimicrobial activity depends on the composition of EOs and the susceptibility of each particular microorganism to the antimicrobial agent. In that work, edible coatings containing thyme evidenced higher antimicrobial activity against $E$. coli, while films formed from sage oil presented higher transparency, WVP and flexibility than those formed from thyme and LO. Also, Kim et al. [64] demonstrated the stability of emulsions based on carnauba wax and LO was enhanced by forming nano-emulsions using dynamic high pressure (DHP) process. The coatings were applied on grape berries, showing antimicrobial activity against Salmonella typhimurium and E. coli $\mathrm{O} 157: \mathrm{H} 7$ during storage at 4 and $25{ }^{\circ} \mathrm{C}$ for 28 days. The coatings allowed reducing loss of weight, total anthocyanin concentration, antioxidant activity and firmness, and also avoided the degradation of phenolic compounds; while they did not significantly change the flavor of the berries. Salvia-Trujillo et al. [103] evaluated another coating with nano-emulsions based on alginate and LO $(0.1,0.5$ and $2 \% \mathrm{v} / \mathrm{v})$ and compared its effect with conventional coatings on the safety and quality attributes of fresh-cut Fuji apples during cold storage. Edible coatings with LO droplets in nano-size showed a better inactivation of $E$. coli than conventional emulsions. Higher LO concentration $(0.5$ or $1 \% \mathrm{v} / \mathrm{v})$ allowed significant browning, but not on those coated with $0.1 \%(\mathrm{v} / \mathrm{v})$ of LO. Also, the respiration of fresh-cut apples was reduced when increasing concentration of LO, but droplet size showed no significant influence on the quality parameters.

Incorporation of antimicrobial agents into edible films allows using small antimicrobial concentrations and low diffusion rates; then their activity can be prolonged during produce distribution, transport and storage. However, it is important to modulate the release rate and migration of antimicrobial compounds from the edible coating matrix. The use of release kinetics models allows estimating optimal active agent concentrations during postharvest storage periods; an example is reported by Del Nobile et al. [30], which determined that Fick's second law properly describes the release kinetics of thymol from zein films at 5, 10, 20 and $35 \%$ (weight of thymol/weight of dry polymer) and that thymol diffusion coefficient is independent from thymol concentration. Some examples of antimicrobial edible coatings showing efficiency on the control of rot pathogens of several fruits and vegetables are presented in Table 2 .

\section{Edible Coating Selection and Application}

Successful application of coatings depends on the selection of the adequate method, which can be chosen between dipping, brushing, spraying and panning [128]. These procedures can be selected based on surface characteristics of the produce and the main purpose of the coating. The most common coating procedure implies wetting the produce by the coating mixture followed by an adhesion process, where the penetration of the solution into the produce's skin occurs [58]. The wetting phase (governed by the surface's spreadability) is crucial, because if the affinity of the coating for the produce is optimal, the time required for this operation is minimal allowing virtually spontaneous spreading of the coating solution [82].

Before deciding on coating application, it is necessary to take into account the two ripening patterns of the produce (climacteric and non-climacteric), in order to select the optimal coating in each case. Climacteric fruits (e.g., tomato, banana, avocado and apple) are characterized by increased respiration and ethylene production rates during ripening. The harvest of this type of produce is recommended as soon as possible, once its physiological maturity is reached. Nevertheless, they ripen rapidly during transport and storage; thus, some of the challenges are to prevent ripening by slowing down respiration and preventing dehydration. Application of coatings able to reduce the ethylene production rate and to control gas exchange $\left(\mathrm{CO}_{2} /\right.$ $\mathrm{O}_{2}$ ) is a possibility for postharvest control of climacteric fruits, in such a way that they can delay the maturing process [7]. Adequate coatings for this kind of fruits are those based on blends of polysaccharides, proteins and/or lipids, since blends can allow overcoming deficiencies of particular components. For example, blends of polysaccharides and additives (e.g., glycerol and lipids) can improve the permeability to gases and water vapor transfer when compared with polysaccharides alone [23]. Lima et al. [71] reported the effectiveness of galactomannan- 
Table 2 Examples of applications of antimicrobial edible coatings in fruits and vegetables

\begin{tabular}{|c|c|c|c|c|}
\hline Matrix & Antimicrobial agent & Microorganisms target & Fruit/vegetable & References \\
\hline $\begin{array}{l}\text { Hydroxypropyl } \\
\text { methylcellulose } \\
\text { and beewax }\end{array}$ & Ammonium carbonate & Botrytis cinerea & Cherry tomatoes & Fagundes et al. [39] \\
\hline Pullulan & Sweet basil extract & Rhizopus arrhizus & Apple & Synowiec et al. [112] \\
\hline Chitosan & Lemon essential oil & Botrytis cinerea & Strawberry & Perdones et al. [91] \\
\hline Gum arabic & Cinnamon oil & $\begin{array}{l}\text { Colletotrichum musae and } \\
\text { Colletotrichum } \\
\text { gloeosporioides }\end{array}$ & Banana and papaya & Maqbool et al. [75] \\
\hline $\begin{array}{l}\text { Mesquite-based } \\
\text { gum }\end{array}$ & $\begin{array}{l}\text { Thyme and Mexican lime } \\
\text { essential oils }\end{array}$ & $\begin{array}{l}\text { Colletotrichum } \\
\text { gloeosporioides and } \\
\text { Rhizopus stolonifer }\end{array}$ & Papaya & Bosquez-Molina et al. [13] \\
\hline Chitosan & Grapefruit seed extract & Botrytis cinerea & Redglobe table grapes & Xu et al. [125] \\
\hline Chitosan & Calcium chloride & $\begin{array}{l}\text { Decreases the microbial } \\
\text { growth rate (fungi and } \\
\text { bacteria) }\end{array}$ & Strawberries & Ribeiro et al. [100] \\
\hline
\end{tabular}

collagen blends in reducing $\mathrm{O}_{2}$ consumption rate by $28 \%$ and $\mathrm{CO}_{2}$ production rate by $11 \%$ when compared with uncoated mangoes, and both rates by $50 \%$ when compared with uncoated apples, respectively.

In non-climacteric fruits (e.g., citrus, pineapples, strawberry and grapes), respiration shows no dramatic change and ethylene is not required for fruit ripening [50], being the losses mostly related to weight loss during transportation. For non-climacteric fruits, it is a common practice to apply lipid-based coatings (e.g., waxes and resins) where the low permeability to $\mathrm{CO}_{2}, \mathrm{O}_{2}$ and water vapor allows reducing metabolic rates and water loss, while also providing an attractive appearance to the produce [7]. Nevertheless, excessive restriction of gas exchange sometimes occurs in waxed fruits, leading to undesirable flavor changes [8, 53, 114]. Blends of lipids and polysaccharides can be used instead to provide appropriate gas and moisture barrier [92]. Furthermore, it has been demonstrated that when polysaccharides solutions are applied at higher concentrations (e.g., chitosan), respiration can be reduced together with changes in weight loss, firmness and external color in strawberry fruits [57].

In addition to the issues mentioned above, in both cases (climacteric and non-climacteric fruits), it is important to take into account temperature control, due to the impact that it shows in fruits' respiration rate. In fact, respiration rate significantly increases or decreases when temperatures are increased or decreased, respectively. This temperature effect must be taken into consideration since even coatings built for ideal storage temperatures can cause anaerobic fermentation and physiological disorders [7] if respiration rates are significantly changed.

Different formulations of edible coatings are available commercially; examples of products well-known in the market are:
1. NatureSeal ${ }^{\circledR}$ (Mantrose-Haeuser, Co., Inc., Westport, CT, USA). Based in ascorbic acid, calcium chloride, hydroxypropyl methylcellulose, it inhibits enzymatic browning, maintains taste, texture, and color of freshcut fruits and vegetables;

2. Pro-long ${ }^{\mathrm{TM}}$ or TAL Pro-long ${ }^{\mathrm{TM}}$ (Courtaulds Ltd., Derby, United Kingdom) is an aqueous dispersion of sucrose polyesters of fatty acids and sodium salt of carboxymethylcellulose; it modifies the internal atmosphere of the fruit and maintains its natural color;

3. Semperfresh ${ }^{\mathrm{TM}}$ (Agricoat Industries Ltd., Seattle, WA, USA) is a mixture of sucrose esters of short-chain unsaturated fatty acids and sodium salts of carboxymethylcellulose; it is a coating developed for the postharvest protection of fruits such as melons, pears, pineapples or cherries;it allows reduction in the respiration rate, ripening, weight loss and conserves the natural color of fruits [5].

New promising natural products have been recently introduced such as:

1. Clarity Citrus (Fagro Post Harvest Solutions S.A. DE C.V., Ramos Arizpe, Mexico), composed of polyethylene, shellac and carnauba; it is specially formulated for citrus fruits at postharvest stage and acts reducing gas exchange, the ripening process and water loss;

2. Naturcover (Decco Ibérica Post Cosecha S.A.U., Valencia, Spain), based on sucrose esters of fatty acids and other additives; it is an edible coating that reduces weight loss and chilling injury in stone fruit, and delays ripening in apples and pears. It also reduces stains of scratches on pears and maintains freshness in citrus fruits; 
3. Foodcoat Fr Drencher DMC (Domca S.A.U., Granada Spain) is formulated from oil acids derivates; it acts reducing the respiration rates of some fruits and vegetables, diminishes fruit weight loss and retards ripening. It also helps enhancing natural brightness and maintaining fruit consistence [86].

\section{Emerging Technologies: Development of Nano- laminate Coatings}

Edible coatings can be considered an effective postharvest technology for extending shelf life of fruits and vegetables. However, their application still faces a number of disadvantages since: (1) they can impart off-flavors associated with the flavor of coating materials and to their deterioration (e.g., rancidity of lipids); (2) they may have their own color and be possibly unattractive for consumers; (3) they can provide an undesirable tacky consistence; (4) it is difficult to obtain an adequate homogeneity for each produce surface being necessary to optimize the application and the drying step conditions; and (5) despite being good carriers of bioactive agents, coatings can require large amounts of those compounds in order to reach optimal effectiveness, and sometimes this incorporation presents difficulties.

All of these problems have been studied in the last years, being the solutions presented in most of the cases based in the use of new emerging technologies. One of the examples is the use of nanotechnology. Nanotechnology uses materials at nanoscale $(\leq 100 \mathrm{~nm})$, exploiting differences in physicochemical properties exhibited by these materials when compared with those at a larger scale [51]. It represents a new tool for food technologists in the food packing area by promising packaging materials that will guarantee food products with a longer shelf life, maintaining their safety and quality [87].

On the other hand, one technique that explores the nanoscale advantages is Layer-by-Layer (LbL) deposition which can be used for nano-laminate coatings formation. It consists in the use of two or more layers of, e.g., oppositely charged materials with nanometer dimension (1-100 nm per layer) that are physically or chemically bound to each other and are assembled layer-wise on core materials [29, 69, 127].

The LbL technique is quite simple and enables using a wide range of materials (e.g., proteins, polysaccharides, lipids, and nanoparticles). These materials are able to interact either by electrostatic interactions, hydrogen bonding, covalent bonds, complementary base pairing and hydrophobic bonding. Moreover, depending on the template used (e.g., planar and colloidal), it is possible to design a variety of nano-laminate systems including nanoemulsions, nano-films and nano-capsules [22].

The resulting properties of nano-laminate coatings such as mechanical properties, gas permeability and swelling and wetting characteristics are influenced by the kind of adsorbing materials utilized and also by the sequence, the total number of layers and the conditions used for preparation (e.g., temperature, $\mathrm{pH}$ and ionic strength) [123]. This leads to a great number of possibilities, thus allowing tailoring the final properties of the coating in order to ensure the desired functionality.

One of the advantages of these nano-systems is their gas barrier properties when compared with conventional edible coatings. Table 3 shows the permeabilities to oxygen and water vapor of conventional and nano-laminate coatings. It is suggested that barrier properties of nano-laminate coatings are improved due to their nano-structure, which has an increased tortuosity resulting from the electrostatic interactions between the nano-laminate's components and also from the interpenetration of the successively deposited layers that hampers gas molecules migration through the structure $[61,79,94]$. The application of LbL technique in fruits and vegetables is very recent, and few studies showed its effect on shelf-life parameters. One of the first steps in the application of LbL technique in produce is to prove its success (by means of microscopy techniques and/or contact angle measurements). Figure $2 \mathrm{~b}$ shows a nano-laminate

Table 3 Water vapor (WVP) and $\mathrm{O}_{2}$ permeabilities $\left(\mathrm{O}_{2} \mathrm{P}\right)$ values of conventional edible coatings and nano-laminate coatings

\begin{tabular}{llllll}
\hline Composition & Type & $\begin{array}{l}\mathrm{WVP} \times 10^{-11} \\
\left(\mathrm{gm}^{-1} \mathrm{~s}^{-1} \mathrm{~Pa}^{-1}\right)\end{array}$ & $\begin{array}{l}\mathrm{O} 2 \mathrm{P} \times 10^{-14} \\
\left(\mathrm{gm}^{-1} \mathrm{~s}^{-1} \mathrm{~Pa}^{-1}\right)\end{array}$ & Thickness $(\mu \mathrm{m})$ & References \\
\hline Starch & Coating & 17.7 & $\mathrm{ND}$ & 69.2 & Garcia et al. [48] \\
l-carrageenan & Coating & $11.80-235^{\mathrm{a}}$ & 720 & 50 & Hambleton et al. [54] \\
Chitosan & Coating & 8.60 & 0.71 & 50 & Fajardo et al. [40] \\
Alginate and chitosan & Nano-laminate & 0.85 & $\mathrm{ND}$ & 0.12 & Carneiro-da-Cunha et al. [19] \\
K-carrageenan and chitosan & Nano-laminate & 0.020 & 0.043 & 0.342 & Pinheiro et al. [94] \\
Pectin and chitosan & Nano-laminate & 0.019 & 0.069 & 0.266 & Medeiros et al. [79] \\
\hline
\end{tabular}

$N D$ not determined

${ }^{a}$ Depending on temperature and humidity gradient 

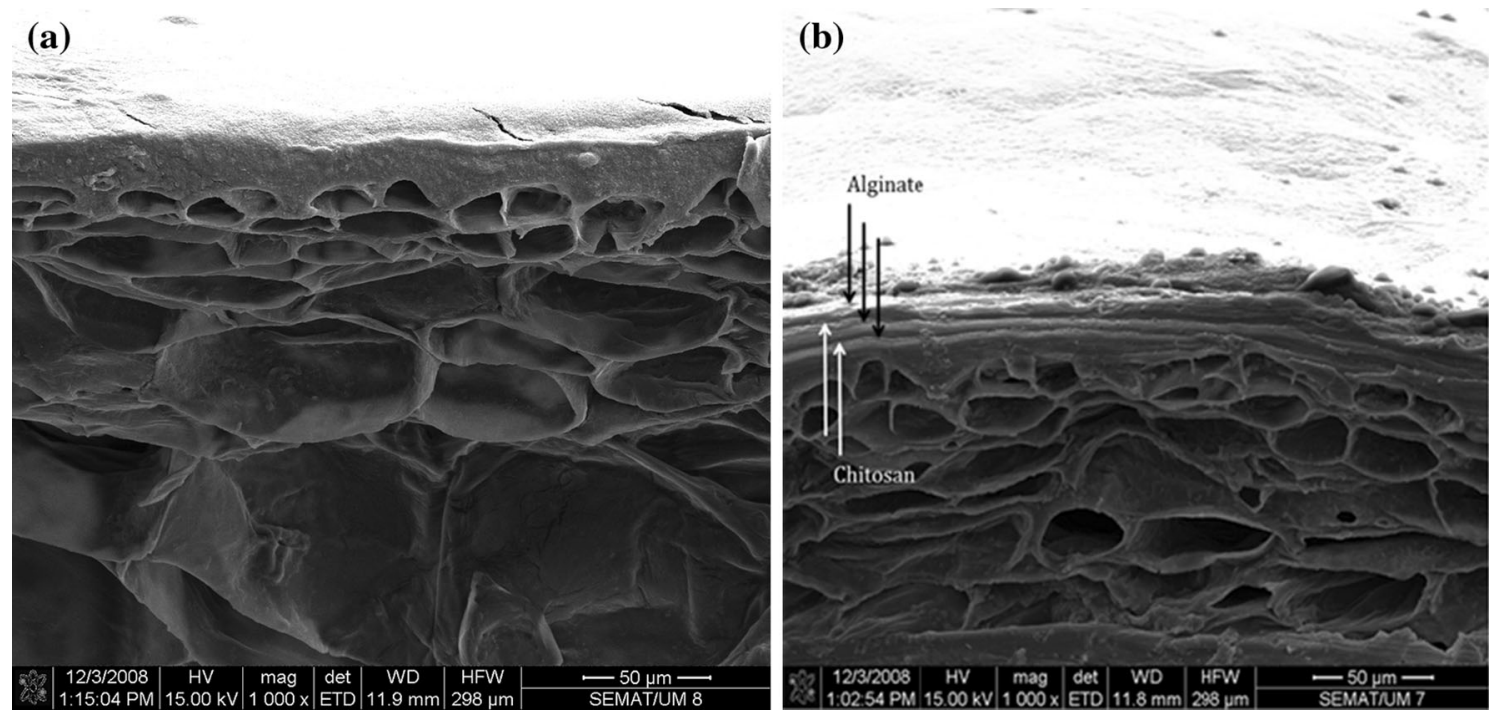

Fig. 2 Scanning electron microscopy images of the mango surface (a) and of nano-laminate coating on mango surface (alginate/chitosan/ alginate/chitosan/alginate) (b)

coating on mangoes surface by means of scanning electron microscopy (SEM; Fig. 2) where it is clear the alternate deposition of alginate and chitosan on mangoes' surface when compared with mango without nano-laminate coating (Fig. 2a).

Application of coatings or waxes at industrial level is typically conducted by micro-spraying using specific nozzles with a bed of propylene brushes or by direct immersion of the food products. The products go through a washing and disinfection step (most cases), being perfectly dried before the coating step. For the application by spraying, the products are rotating while the coating/wax is adhered to the surface. Drying steps can be performed in a tunnel with strong ventilation $\left(40-45^{\circ} \mathrm{C}\right)$ between 1.5 and $2.0 \mathrm{~min}$ or at room temperature. As far as we know, nanolaminate coatings have not been applied at industrial level. In our opinion for a successful application of nano-laminate coatings, the immersion method should be used with washing (in water) and drying (at temperatures around $30{ }^{\circ} \mathrm{C}$ with strong ventilation) steps between layer applications. The times for this process as evaluated at laboratory scale are around 10-20 min, but a re-evaluation/ adaptation is necessary in order to be applied at industrial scale. It is important to mention that there are studies referring the possibility of using spraying in the development of multilayers [106].

Recent works showed successful applications of nanolaminate coatings in commodities describing the application conditions, such as number of layers, immersion time, washing and drying steps. Medeiros et al. [79] evaluated a nano-laminate coating based on five layers of pectin and chitosan (at a concentration of $0.2 \%, \mathrm{w} / \mathrm{v}$ ) on whole
"Tommy Atkins" mangoes applied by immersion of 15 min into each polyelectrolyte solution and a washing procedure with distilled water at $\mathrm{pH} 7.0$ and 3.0 for pectin and chitosan, respectively. After 45 days, the coated mangoes presented better appearance, reduction in water loss, and absence of fungal growth that uncoated mangoes; also, reduction in gas flow was observed, as a result the shelf life of mangoes was increased. Moreover, Medeiros et al. [80] reported the positive effect on shelf-life extension of Rocha' fresh-cut pears (CP) and whole pears (WP) upon application of a nano-laminate coating composed of five layers of $\kappa$-carrageenan and lysozyme (each at concentrations of $0.2 \%, \mathrm{w} / \mathrm{v})$. The immersion time into each polyelectrolyte solution was 5 and 15 min for $\mathrm{CP}$ and WP, respectively, and subsequently rinsed with deionized water with $\mathrm{pH} 7.0$ ( $\kappa$-carrageenan) and $\mathrm{pH} 3.8$ (lysozyme). The coating avoided mass loss of $\mathrm{CP}$, proving the efficiency of the nano-laminate as water loss barrier. Total soluble solids values were lower for both coated $\mathrm{CP}$ and coated WP during the experimental period (7 and 45 days, respectively); while low values of titratable acidity for coated CP and WP were an indicative of the delay in maturation process associated with the reduction in gas exchange $\left(\mathrm{O}_{2}\right.$ and $\mathrm{CO}_{2}$ ) by the application of the coating. More recently, Souza et al. [109] studied a nano-laminate coating based on five alternate layers of alginate and chitosan (each at concentrations of $0.2 \%, \mathrm{w} / \mathrm{v}$ ) to extend the shelf life of fresh-cut mangoes stored under refrigeration $\left(8^{\circ} \mathrm{C}\right)$ for 14 days. Polyelectrolyte solutions were applied by immersion for $15 \mathrm{~min}$ and subsequently rinsed with deionized water with $\mathrm{pH} 7.0$ and 3.0 for alginate and chitosan, respectively. An additional drying step with flow of 
nitrogen at $25{ }^{\circ} \mathrm{C}$ for $15 \mathrm{~min}$ was used between layers. Lower values of soluble solids, mass loss and higher titratable acidity were observed on coated fresh-cut mangoes. Moreover, the nano-laminate allowed the reduction in malondialdehyde content (an indication that the coating application prevents senescence). According to microbial analyses, the shelf life of fresh-cut mangoes was increased up to 8 days at $8^{\circ} \mathrm{C}$ when compared with uncoated freshcut mangoes $(<2$ days).

Nano-laminate coatings are able to incorporate functional compounds under the form of nanoparticles, which presumably have greater chemical reactivity and can be more bioactive than larger particles as their size has better access to any structure [73]. Furthermore, nanoparticles can have a dual purpose: besides acting as carriers of additives, they may also provide improvements in the mechanical and barrier properties of the structures where they can be incorporated. However, the efficiency of nanolayer systems with a variety of features (e.g., antioxidant, antimicrobial and reduction in gas exchange) still remains little studied.

The use of LbL technique has also been studied at microscale; some examples are reported by Brasil et al. [16]. In this work, a microencapsulated beta-cyclodextrin and trans-cinnamaldehyde complex $(2 \mathrm{~g} / 100 \mathrm{~g})$ was incorporated into a laminate coating made of chitosan and pectin; the quality of fresh-cut papaya was extended to 15 days at $4{ }^{\circ} \mathrm{C}$ while uncoated fruits could not reach this far ( $<7$ days). The coating reduced the losses of Vitamin $\mathrm{C}$ and total carotenoids content; in addition, the encapsulation of trans-cinnamaldehyde was successful, since it had no negative impact on the fruit's flavor. In another work, Mantilla et al. [74] evaluated the efficacy of a microencapsulated antimicrobial complex (beta-cyclodextrin and trans-cinnamaldehyde) incorporated into a laminate coating composed of pectin-alginate on fresh-cut pineapples. The system showed microbial growth inhibition, while the original qualities (color, texture and $\mathrm{pH}$ ) of pineapples were kept and the shelf life was extended to 15 days at $4{ }^{\circ} \mathrm{C}$.

\section{Conclusion}

One of the major causes of postharvest losses in fruits and vegetables worldwide is the lack of postharvest technology solutions in developing countries. One of the solutions is the application of edible coatings, where nano-laminate coatings showed in the last years to be one of the promising technologies to increase fruits shelf life. Despite the promising results is still needed an appropriate optimization and implementation of these technologies, in order to be effectively used in the processing chain of fruits and vegetables.

The use of nanotechnology promises a great impact in food and agriculture industries. Nanotechnology advanced not only in packaging technologies, through the development of nano-laminate and bioactive nano-laminate coatings for application on fruits and vegetables, but also in the design of biosensors to identify and quantify diseases, residuals of agrochemicals, modification of food composition, and in the nano-formulation of agrochemicals to control pests and application of fertilizers. However, optimization and implementation of these technologies still faces some challenges, e.g., difficulty measuring the nanolaminate coatings' thickness (nanoscale); and industry viability, due to the changes needed in packing-houses for the application of nano-laminate coatings.

Acknowledgments María L. Flores-López thanks Mexican Science and Technology Council (CONACYT, Mexico) for PhD fellowship support (CONACYT Grant Number: 215499/310847). Miguel A. Cerqueira (SFRH/BPD/72753/2010) is recipient of a fellowship from the Fundação para a Ciência e Tecnologia (FCT, POPH-QREN and FSE Portugal). The authors also thank the FCT Strategic Project of UID/ BIO/04469/2013 unit, the project RECI/BBB-EBI/0179/2012 (FCOMP-01-0124-FEDER-027462) and the project "BioInd Biotechnology and Bioengineering for improved Industrial and AgroFood processes," REF. NORTE-07-0124-FEDER-000028 Co-funded by the Programa Operacional Regional do Norte (ON.2 - O Novo Norte), QREN, FEDER. Fundação Cearense de Apoio ao Desenvolvimento Científico e Tecnológico - FUNCAP, CE Brazil (CI10080-00055.01.00/13).

\section{References}

1. Acevedo-Fani A, Salvia-Trujillo L, Rojas-Grä̈ MA, MartínBelloso O (2015) Edible films from essential-oil-loaded nanoemulsions: physicochemical characterization and antimicrobial properties. Food Hydrocoll 47:168-177

2. Ahmad M, Benjakul S, Prodpran T, Agustini TW (2012) Physico-mechanical and antimicrobial properties of gelatin film from the skin of unicorn leatherjacket incorporated with essential oils. Food Hydrocoll 28(1):189-199

3. Avena-Bustillos RJ, Krochta JM (1993) Water vapor permeability of caseinate-based edible films as affected by $\mathrm{pH}$, calcium crosslinking and lipid concentration. J Food Sci 58(4):904-907

4. Ayrancy E, Tunc S (2003) A method for measurement of the oxygen permeability and development of edible films to reduce the rate of oxidative reactions in fresh foods. Food Chem 80:423-431

5. Bai J, Plotto A (2012) Chapter 7 Edible coatings and films to improve food quality. In: Baldwin EA, Hagenmaier R, Bai J (eds) Coatings for fresh fruits and vegetables, 2nd edn. FL, USA, pp 186-242

6. Bailey A, Chandler D, Grant WP, Greaves J, Prince G, Tatchell $M$ (2010) Biopesticides: pest management and regulation. CAB International, Tucson, pp 71-75

7. Baldwin E (2001) New coating formulations for the conservation of tropical fruits. In: Fruit conservation and processing: new issues, new techniques. Montpellier, France 
8. Baldwin EA (1995) Edible coatings for lightly processed fruits and vegetables. HortScience 30(1):35-38

9. Barry-Ryan C, Martin-Diana A, Rico D, Barat J (2007) Extending and measuring the quality of fresh-cut fruit and vegetables - a review. Trends Food Sci Technol 18:373-386

10. Batta YA (2007) Control of postharvest diseases of fruit with and invert emulsion formulation of Trichoderma harzianum Rifai. Postharvest Biol Technol 43:143-150

11. Ben-Yehoshua S, Rodov V (2003) Transpiration and water stress. In: Bartz JA, Brecht JK (eds) Postharvest physiology and pathology of vegetables, 2nd edn. Marcel Dekker, Inc., New York, Basel, pp 111-159

12. Bergo P, Sobral PJA (2007) Effects of plasticizer on physical properties of pigskin gelatin films. Food Hydrocoll 21:1285-1289

13. Bosquez-Molina E, Ronquillo-de Jesús E, Bautista-Baños S, Verde-Calvo JR, Morales-López J (2010) Inhibitory effect of essential oils against Colletotrichum gloeosporioides and Rhizopus stolonifer in stored papaya fruit and their possible application in coatings. Postharvest Biol Technol 57:132-137

14. Bourtoom T (2008) Edible films and coatings: characteristics and properties. Int Food Res J 15(3):237-248

15. Bourtoom T (2009) Edible protein films: properties enhancement. Int Food Res J 16:1-9

16. Brasil IM, Gomes C, Puerta-Gomez A, Castell-Perez ME, Moreira RG (2012) Polysaccharide-based multilayered antimicrobial edible coating enhances quality of fresh-cut papaya. LWT Food Sci Technol 47:39-45

17. Calvo J, Calvente V, de Orellano ME, Benuzzi D, Sanz de Tosetti MI (2007) Biological control of postharvest spoilage caused by Penicillium expansum and Botrytis cinerea in apple by using the bacterium Rahnella aquatilis. Int J Food Microbiol 113:251-257

18. Cañamás TP, Viñas I, Usall J, Casals C, Solsona C, Teixidó N (2008) Control of postharvest diseases on citrus fruit by preharvest application of the biocontrol agent Pantoea agglomerans CPA-2: part I. Study of different formulation strategies to improve survival of cells in unfavourable environmental conditions. Postharvest Biol Technol 49(1):86-95

19. Carneiro-da-Cunha MG, Cerqueira MA, Souza BWS, Carvalho S, Quintas MAC, Teixeira JA, Vicente AA (2010) Physical and thermal properties of a chitosan/alginate nanolayered PET film. Carbohydr Polym 82(1):153-159

20. Castillo F, Hernández D, Gallegos G, Mendez M, Rodríguez R, Reyes A, Aguilar CN (2010) In vitro antifungal activity of plant extracts obtained with alternative organic solvents against $R h i$ zoctonia solani Kühn. Ind Crops Prod 32(3):324-328

21. Cerqueira MA, Lima AM, Teixeira JA, Moreira RA, Vicente AA (2009) Suitability of novel galactomannans as edible coatings for tropical fruits. J Food Eng 94:372-378

22. Cerqueira MA, Pinheiro AC, Silva HD, Ramos PE, Azevedo MA, Flores-López ML, Rivera MC, Bourbon AI, Ramos OL, Vicente AA (2014) Design of bio-nanosystems for oral delivery of functional compounds. Food Eng Rev 6(1-2):1-19

23. Cerqueira MA, Souza BWS, Teixeira JA, Vicente AA (2012) Effect of glycerol and corn oil on physicochemical properties of polysaccharide films - a comparative study. Food Hydrocoll 27:175-184

24. Chandler D, Bailey AS, Tatchell GM, Davidson G, Greaves J, Grant WP (2011) The development, regulation and use of biopesticides for integrated pest management. Philos Trans R Soc Lond Ser B 336:1987-1998

25. Chiumarelli M, Hubinger MD (2014) Evaluation of edible films and coatings formulated with cassava starch, glycerol, carnauba wax and stearic acid. Food Hydrocoll 38:20-27

26. Datta SC (2003) Plant physiology. New Age International (ed), New Delhi, pp 92-96
27. De Costa DM, Erabadupitiya HRUT (2005) An integrated method to control postharvest diseases of banana using a member of the Burkholderia cepacia complex. Postharvest Biol Technol 36:31-39

28. Debeaufort F, Voilley A (2009) Chapter 5 Lipid-based edible films and coatings. In: Embuscado ME, Huber KC (eds) Edible films and coatings for food applications. Springer, USA, pp 135-168

29. Decher G, Schlenoff JB (eds) (2002) Multilayer thin films. Sequential assembly of nanocomposite materials. Wiley, Weinheim, pp 1-31

30. Del Nobile MA, Conte A, Incoronato AL, Panza O (2008) Antimicrobial efficacy and release kinetics of thymol from zein films. J Food Eng 89:57-63

31. Dhall RK (2013) Advances in edible coatings for fresh fruits and vegetables: a review. Crit Rev Food Sci Nutr 53:435-450

32. Dou H (2004) Effect of coating application on chilling injury of grapefruit cultivars. HortScience 39(3):558-561

33. Droby S, Wisniewski M, Macarisin D, Wilson C (2009) Twenty years of postharvest biocontrol research: is it time for a new paradigm? Postharvest Biol Technol 52:137-145

34. Droby S, Wisniewsko ME, El-Ghaouth A, Wilson CL (2003) Influence of food additives on the control of postharvest rots of apple and peach and efficacy of the yeast-based biocontrol product aspire. Postharvest Biol Technol 27(2):127-135

35. EPA (Environmental Protection Agency) (2014) Regulating biopesticides. http://www.epa.gov/oppbppd1/biopesticides/index.html

36. Eshel D, Regev F, Orenstein J, Droby S, Gan-Mor S (2009) Combining physical, chemical and biological methods for synergistic control of postharvest diseases: a case study of Black Root Rot of carrot. Postharvest Biol Technol 54(1):4852

37. European Commission (EC) (2011) Regulation (EU) 1130/2011 of 11 November 2011 amending Annex III to Regulation (EC) No 1333/2008 of the European Parliament and of the Council on food additives by establishing a Union list of food additives approved for use in food additives, food enzymes, food flavourings and nutrients. Off J Eur Union L295:1

38. Fabra MJ, Jiménez A, Atarés P, Talens P, Chiralt A (2009) Effect of fatty acids and beeswax addition on properties of sodium caseinate dispersions and films. Biomacromolecules 10:1500-1507

39. Fagundes C, Palou L, Monteiro AR, Pérez-Gago MB (2014) Effect of antifungal hydroxypropyl methylcellulose-beeswax edible coatings on gray mold development and quality attributes of cold-stored cherry tomato fruit. Postharvest Biol Technol 92:1-8

40. Fajardo P, Martins JT, Fucinos C, Pastrana L, Teixeira JA, Vicente AA (2010) Evaluation of a chitosan-based edible film as carrier of natamycin to improve the storability of Saloio cheese. J Food Eng 101(4):349-356

41. Falguera V, Quintero JP, Jiménez A, Aldemar Muñoz J, Ibarz A (2011) Edible films and coatings: structures, active functions and trends in their use. Trends Food Sci Technol 22(6):292-303

42. FAO (1989) Prevention of post-harvest food losses: fruits, vegetables and root crops. A training manual. FAO Corporate Document Repository. http://www.fao.org/docrep/T0073E/ T0073E00.htm

43. Galietta G, Di Gioia L, Guilbert S, Cuq B (1998) Mechanical and thermomechanical properties of films based on whey proteins as affected by plasticizers and crosslinking agents. J Dairy Sci 81:3123-3130

44. Galietta G, Vanya F, Ferrari N, Diano W (1998) Barrier properties of whey protein isolate films to carbon dioxide and ethylene at various water activities. In: Colonna P, Guilber S (eds) Biopolymer science: food and non food applications. Les colloques No. 91. INRA Editions, Montepellier, pp 327-335 
45. Galus S, Lenart A (2013) Development and characterization of composite edible films based on sodium alginate and pectin. J Food Eng 115(4):459-465

46. Galus S, Lenart A, Voilley A, Debeaufort F (2013) Effect of oxidized potato sarch on the physicochemical properties of soy protein isolate-based edible films. Food Technol Biotechnol 51(3):403-409

47. Garcia MA, Martino MN, Zaritzky NE (2000) Lipid addition to improve barrier properties of edible starch-based films and coatings. J Food Sci 65(6):941-947

48. Garcia MA, Pinotti A, Zaritzky NE (2006) Physicochemical, water vapor barrier and mechanical properties of corn starch and chitosan composite films. Starch/Stärke 58:453-463

49. Gatto MA, Ippolito A, Linsalata V, Cascarano NA, Nigro F, Vanadia S, Di Venere D (2011) Activity of extracts from wild edible herbs against postharvest fungal diseases of fruit and vegetables. Postharvest Biol Technol 61(1):72-82

50. Giovannoni J (2001) Molecular biology of fruit maturation and ripening. Annu Rev Plant Physiol Plant Mol Biol 52:725-729

51. Granda-Valdés M, Váldes-González AC, García-Calzón JA, Díaz-García ME (2009) Analytical nanotechnology for food analysis. Microchim Acta 166:1-19

52. Gustavsson J, Cederberg C, Sonesson U, van Otterdijk R, Meybeck A (2011) Food losses and food waste: extent, causes and prevention. FAO, Rome, pp 1-29

53. Hagenmaier RD (2002) The flavor of mandarin hybrids with different coatings. Postharvest Biol Technol 24:79-87

54. Hambleton A, Debeaufort F, Beney L, Karbowiak T, Voilley A (2008) Protection of active aroma compound against moisture and oxygen by encapsulation in biopolymeric emulsion-based edible films. Biomacromolecules 9:1058-1063

55. Hamzah HM, Osman A, Tan CP, Ghazali FM (2013) Carrageenan as an alternative coating for papaya (Carica papaya $\mathrm{L}$. cv. Eksotika). Postharvest Biol Technol 75:142-146

56. Henriod RE (2006) Postharvest characteristics of navel oranges following high humidity and low temperature storage and transport. Postharvest Biol Technol 42:57-64

57. Hernández-Muñoz P, Almenar E, Del Valle V, Velez D, Gavara $\mathrm{R}$ (2008) Effect of chitosan coating combined with postharvest calcium treatment on strawberry (Fragaria $\times$ ananassa) quality during refrigerated storage. Food Chem 110:428-435

58. Hershko V, Klein E, Nussinovitch A (1996) Relationships between edible coatings and garlic skin. J Food Sci 61(4):769777

59. Hong P, Hao W, Luo J, Chen S, Hu M, Zhong G (2014) Combination of hot water, Bacillus amyloliquefaciens HF-01 and sodium bicarbonate treatments to control postharvest decay of mandarin fruit. Postharvest Biol Technol 88:96-102

60. James IF, Kuipers B (2003) Preservation of fruit and vegetables, 4th edn. Agromisa Foundation, Wageningen, pp 1-12

61. Jang SG, Choi DG, Heo CJ, Lee SY, Yang SM (2008) Nanoscopic ordered voids and metal caps by controlled trapping of colloidal particles at polymeric film surfaces. Adv Mater 20:4862-4867

62. Jasso de Rodríguez D, Rodríguez-García R, Hernánde-Castillo FD, Aguilar-González CN, Sáenz-Galindo A, Villarreal-Quintanilla JA, Moreno-Zuccolotto LE (2011) In vitro antifungal activity of extracts of Mexican Chihuahuan Desert plants against postharvest fruit fungi. Ind Crops Prod 34(1):960-966

63. Kester JJ, Fennema OR (1986) Edible film and coatings: a review. Food Technol 40:47-59

64. Kim IH, Oh YA, Lee H, Song KB, Min SC (2014) Grape berry coatings of lemongrass oil-incorporating nanoemulsion. LWT Food Sci Technol 58(1):1-10

65. Kitinoja L (2010) Identification of appropriate postharvest technologies for improving market access and incomes for small horticultural farmers in Sub-Saharan Africa and South Asia. Part 2: Postharvest Loss Assessments. World Food Logistic Organization, pp 1-22

66. Kitinoja L, Saran S, Roy SK, Kader AA (2011) Postharvest technology for developing countries: challenges and opportunities in research, outreach and advocacy. J Sci Food Agric 91:597-603

67. Kotan R, Cakir A, Ozer H, Kordali S, Cakmakci R, Dadasoglu F, Dikbas N, Aydin T, Kazaz C (2014) Antibacterial effects of Origanum onites against phytopathogenic bacteria: possible use of the extracts from protection of disease caused by some phytopathogenic bacteria. Sci Hortic 172:210-220

68. Kurek M, Galus S, Debeaufort F (2014) Surface, mechanical and barrier properties of bio-based composite films based on chitosan and whey protein. Food Packag Shelf Life 1:56-67

69. Labouta HI, Schneider M (2010) Tailor-made biofunctionalized nanoparticles using layer-by-layer technology. Int $\mathrm{J}$ Pharm 395:236-242

70. Li Q, Ning P, Zheng L, Huang J, Li G, Hsiang T (2012) Effects of volatile substances of Streptomyces globisporus JK-1 on control of Botrytis cinerea on tomato fruit. Biol Control 61(2):113-120

71. Lima AM, Cerqueira MA, Souza BWS, Santos ECM, Teixeira JA, Moreira RA, Vicente AA (2010) New edible coatings composed of galactomannans and colagens blends to improve the postharvest quality of fruits-influence on fruits gas transfer rate. J Food Eng 97:101-109

72. Lin D, Zhao Y (2007) Innovations in the development and application of edible coatings for fresh and minimally processed fruits and vegetables. Compr Rev Food Sci Food Saf 6:60-74

73. Lugo-Medina E, García-Gutiérrez C, Ruelas-Ayala RD (2010) Nanotecnología y nanoencapsulación de plaguicidas. Ra Ximhai 6(1):63-67

74. Mantilla N, Castell-Perez ME, Gomes C, Moreira RG (2013) Multilayered antimicrobial edible coating and its effect on quality and shelf-life of fresh-cut pineapple (Ananas comosus). LWT Food Sci Technol 51:37-43

75. Maqbool M, Ali A, Alderson PG, Mohamed MTM, Siddiqui Y, Zahid N (2011) Postharvest application of gum arabic and essential oils for controlling anthracnose and quality of banana and papaya during cold storage. Postharvest Biol Technol 62:71-76

76. Mari M, Martini C, Spadoni A, Rouissi W, Bertolini P (2012) Biocontrol of apple postharvest decay by Aureobasidium pullulans. Postharvest Biol Technol 73:56-62

77. Martins JT, Cerqueira MA, Vicente AA (2012) Influence of $\alpha$ tocopherol on physicochemical properties of chitosan-based films. Food Hydrocoll 27(1):220-227

78. McCollum TG (2002) Molecular biology of host-pathogen interactions in harvested horticultural crops. HortScience 37(3):12-14

79. Medeiros BGS, Pinheiro AC, Carneiro-da-Cunha MG, Vicente AA (2012) Development and characterization of a nanomultilayer coating of pectin and chitosan-evaluation of its gas barrier properties and application on 'Tommy Atkins' mangoes. J Food Eng 110:457-464

80. Medeiros BGS, Pinheiro AC, Teixeira JA, Vicente AA, Carneiro-da-Cunha MG (2012) Polysaccharide/protein nanomultilayer coatings: construction, characterization and evaluation of their effect on 'Rocha' pear (Pyrus communis L.) shelf-life. Food Bioprocess Technol 5:2435-2445

81. Miller KS, Krochata JM (1997) Oxygen and aroma barrier properties of edible films: a review. Trends Food Sci Technol $8: 228-237$

82. Mittal KL (1977) The role of the interface in adhesion phenomena. Polym Eng Sci 17(7):467-473 
83. Mohamed C, Clementine KA, Didier M, Gérard L, Noëlle DCM (2013) Antimicrobial and physical properties of edible chitosan films enhanced by lactoperoxidase system. Food Hydrocoll 30:576-580

84. Montesinos HE, Palou L, Pastor C, Del Río MA (2006) Evaluación preliminar de aditivos alimentarios para el control de las podredumbres verde y azul en postcosecha de naranja. In: Actas VII Simposio Nacional y V Ibérico de Maduración y Postrecolección. Innovaciones Fisiológicas y Tecnológicas de la Maduración y Post-recolección de Frutas y Hortalizas. Alicante, España, pp 409-412

85. Moreira MR, Ponce A, Ansorena R, Roura SI (2011) Effectiveness of edible coatings combined with mild heat shocks on microbial spoilage and sensory quality of fresh cut broccoli (Brassica oleracea L.). J Food Sci 76(6):367-374

86. Namesny A, Delgado A (2014) Postharvest-the directory for growers, packers, processors and distributors. Especialistes en Serveis per a la Producció Editorial, S.L., Valencia, Spain. pp 26-41

87. Neethirajan S, Jayas DS (2011) Nanotechnology for the food and bioprocessing industries. Food Bioprocess Technol 4(1):39-47

88. Olivas GI, Barbosa-Cánovas GV (2008) Alginate-calcium films: water vapor permeability and mechanical properties as affected by plasticizer and relative humidity. LWT Food Sci Technol 41:359-366

89. Paladines D, Valero D, Valverde JM, Díaz-Mula H, Serrano M, Martínez-Romero D (2014) The addition of rosehip oil improves the beneficial effect of Aloe vera gel on delaying ripening and maintaining postharvest quality of several stonefruit. Postharvest Biol Technol 92:23-28

90. Pavlath AE, Orts W (2009) Chapter 1 edible films and coatings: why, what, and how? In: Embuscado ME, Huber KC (eds) Edible films and coatings for food applications. Springer, USA, pp 1-23

91. Perdones A, Sánchez-González L, Chiralt A, Vargas M (2012) Effect of chitosan-lemon essential oil coatings on storagekeeping quality of strawberry. Postharvest Biol Technol 70:3241

92. Perez-Gago MB, Rojas C, DelRio MA (2002) Effect of lipid type and amount of edible hydroxypropyl methylcellulose-lipid composite coatings used to protect postharvest quality of Mandarins cv. Fortune. J Food Sci 67(8):2903-2910

93. Pérez-Pérez C, Regalado-González C, Rodríguez-Rodríguez CA, Barbosa-Rodríguez JR, Villaseñor-Ortega F (2006) Incorporation of antimicrobial agents in food packaging films and coatings. In: Guevara-González RG, Torres-Pacheco I (eds) Advances in agricultural and food biotechnology. Research Signpost, Kerala, pp 193-216

94. Pinheiro AC, Bourbon AI, Medeiros BGS, da Silva LHM, da Silva MCH, Carneiro-da-Cunha MG, Coimbra MA, Vicente AA (2012) Interactions between $\kappa$-carrageenan and chitosan in nanolayered coatings-structural and transport properties. Carbohydr Polym 87(2):1081-1090

95. Qin Y, Qian C, Zunwei C, Hongke X, Mengna F, Shengchao L, Huizhong W, Maojun X (2012) Activating defense responses and reducing postharvest blue mold decay caused by Penicillium expansum in peach fruit by yeast saccharide. Postharvest Biol Technol 74:100-107

96. Ramos OL, Santos AC, Leão MV, Pereira JO, Silva SI, Fernandes JC, Franco MI, Pintado ME, Malcata XF (2012) Antimicrobial activity of edible coatings prepared from whey protein isolate and formulated with various antimicrobial agents. J Dairy Sci 25(2):132-141

97. Ramos-García ML, Bautista-Baños S, Barrera-Necha LL, Bosquez-Molina E, Alia-Tejacal I, Estrada-Carrillo M (2010) Compuestos antimicrobianos adicionados en recubrimientos comestibles para uso en productos hortofrutícolas. Rev Mex Fitopatol 28:44-57

98. Raybaudi-Massilia RM, Mosqueda-Melgar J, Martín-Belloso O (2008) Edible alginate-based coating as carrier of antimicrobials to improve shelf-life and safety of fresh-cut melon. Int J Food Microbiol 21:313-327

99. Recep K, Fikrettin S, Erkol D, Cafer E (2009) Biological control of the potato dry rot caused by Fusarium species using PGPR strains. Biol Control 50(2):194-198

100. Ribeiro C, Vicente A, Teixeira J, Miranda C (2007) Optimization of edible coating composition to retard strawberry fruit senescence. Postharvest Biol Technol 44:63-70

101. Rojas-Graü MA, Raybaudi-Massilia RM, Soliva-Fortuny RC, Avena-Bustillos RJ, McHugh TH, Martín-Belloso O (2007) Apple puree-alginate edible coating as carrier of antimicrobial agents to prolong shelf-life of fresh-cut apples. Postharvest Biol Technol 45(2):254-264

102. Ruiz HA, Cerqueira MA, Silva HD, Rodríguez Jasso RM, Vicente AA, Teixeira JA (2013) Biorefinery valorization of autohydrolysis wheat straw hemicellulose to be applied in a polymer-blend film. Carbohydr Polym 92:2154-2162

103. Salvia-Trujillo L, Rojas-Graü MA, Soliva-Fortuny R, MartínBelloso O (2015) Use of antimicrobial nanoemulsions as edible coatings: impact on safety and quality attributes of fresh-cut Fuji apples. Postharvest Biol Technol 105:8-16

104. Sánchez-González L, Cháfer M, Chiralt A, González-Martínez C (2010) Physical properties of edible chitosan films containing bergamot essential oil and their inhibitory action on Penicillium italicum. Carbohydr Polym 82(2):277-283

105. Schena L, Nigro F, Pentimone I, Ligorio A, Ippolito A (2003) Control of postharvest rots of sweet cherries and table grapes with endophytic isolates of Aureobasidium pullulans. Postharvest Biol Technol 30(3):209-220

106. Schlenoff JB, Dubas ST, Farhat T (2000) Sprayed polyelectrolyte multilayers. Langmuir 16(26):9968-9969

107. Sothornvita R, Krochtab JM (2005) Plasticizers in edible films and coatings. In: Han JH (ed) Innovations in food packaging. Elsevier Academic Press, San Diego, pp 403-433

108. Souza BWS, Cerqueira MA, Teixeira JA, Vicente AA (2010) The use of electric fields for edible coatings and films development and production: a Review. J Food Eng 2:244-255

109. Souza MP, Vaz AFM, Cerqueira MA, Teixeira JA, Vicente AA, Carneiro-da-Cunha MG (2015) Effect of an edible nanomultilayer coating by electrostatic self-assembly on the shelf life of fresh-cutmangoes. Food Bioprocess Technol 8:647-654

110. Spadaro D, Vola R, Piano S, Gullino ML (2002) Mechanisms of action and efficacy of four isolates of the yeast Metschnikowia pulcherrima active against postharvest pathogens on apples. Postharvest Biol Technol 24(2):123-134

111. Suyatma NE, Tighzert L, Copinet A, Coma V (2005) Effects of hydrophilic plasticizers on mechanical, thermal, and surface properties of chitosan films. J Agric Food Chem 53:3950-3957

112. Synowiec A, Gniewosz M, Kraśniewska K, Przybył JL, Bączek K, Węglarz Z (2014) Antimicrobial and antioxidant properties of pullulan film containing sweet basil extract and an evaluation of coating effectiveness in the prolongation of the shelf life of apples stored in refrigeration conditions. Innov Food Sci Emerg Technol 23:171-181

113. Tapia MS, Rojas-Graü MA, Carmona A, Rodríguez FJ, SolivaFortuny R, Martin-Belloso O (2008) Use of alginate- and gellanbased coatings for improving barrier, texture and nutritional properties of fresh-cut papaya. Food Hydrocoll 22:1493-1503

114. Tietel Z, Bar E, Lewinsohn E, Feldmesser E, Fallik E, Porat R (2010) Effects of wax coatings and postharvest storage on sensory quality and aroma volatile composition of 'Mor'mandarins. J Sci Food Agric 90:995-1007 
115. Trezza TA, Krochta JM (2000) The gloss of edible coatings as affected by surfactants, lipids, relative humidity, and time. J Food Sci 65:658-662

116. Tripathi P, Dubey NK (2004) Exploitation of natural products as an alternative strategy to control postharvest fungal rotting of fruit and vegetables. Postharvest Biol Technol 32:235-245

117. United States Food and Drug Administration (US FDA) (2009) Food additives permitted for direct addition to food for human consumption. Subpart C. Coatings, films and related substances. 21CFR172.210-280. Code Fed Regul 21(3):40-46

118. Valencia-Chamorro SA, Palou L, Del Río MA, Pérez-Gago MB (2011) Antimicrobial edible films and coatings for fresh and minimally processed fruit and vegetables: a review. Crit Rev Food Sci Nutr 51:872-900

119. Valenzuela C, Abugoch L, Tapia C (2013) Quinoa proteinchitosan-sunflower oil edible film: mechanical, barrier and structural properties. LWT Food Sci Technol 50:531-537

120. Valverde JM, Valero D, Martínez-Romero D, Guillén F, Castillo S, Serrano M (2005) Novel edible coating based on Aloe vera gel to maintain table grape quality and safety. J Agric Food Chem 53(20):7807-7813

121. Van Hung D, Tong S, Tanaka F, Yasunaga E, Hamanaka D, Hiruma N, Uchino T (2011) Controlling the weight loss of fresh produce during postharvest storage under a nano-size mist environment. J Food Eng 106:325-330

122. Villaverde JJ, Sevilla-Morán B, Sandín-España P, López-Goti C, Alonso-Prados JL (2014) Biopesticides in the framework of the European Pesticide Regulation (EC) No. 1107/2009. Pest Manag Sci 70:2-5

123. Weiss J, Takhistov P, McClements J (2006) Functional materials in food nanotechnology. J Food Sci 71(9):107-116

124. Wijesinghe CJ, Wilson Wijeratnam RS, Samarasekara JKRR, Wijesundera RLC (2010) Biological control of Thielaviopsis paradoxa on pineapple by an isolate of Trichoderma asperellum. Biol Control 53:285-290

125. Xu WT, Huang KL, Guo F, Qu W, Yang JJ, Liang ZH, Luo YB (2007) Postharvest grapefruit seed extract and chitosan treatments of table grapes to control Botrytis cinerea. Postharvest Biol Technol 46(1):86-94

126. Yahia EM, Barry-Ryan C, Dris R (2004) Treatments and techniques to minimize the postharvest losses of perishable food crops. Prod Pract Qual Assess Food Crops 4:95-133

127. Zhang RJ, Cui JW, Lu DM, Hou WG (2007) Study on highefficiency fluorescent microcapsules doped with europium betadiketone complex by LbL self-assembly. Chem Commun 15:1547-1549

128. Zhao Y (2012) Chapter 10 Application of commercial coatings. In: Baldwin EA, Hagenmaier R, Bai J (eds) Edible coatings and films to improve food quality, 2nd edn. FL, USA, pp 319-331

129. Zimet P, Livney YD (2009) Beta-lactoglobulin and its nanocomplexes with pectin as vehicles for $\omega-3$ polyunsaturated fatty acids. Food Hydrocoll 23:1120-1126 